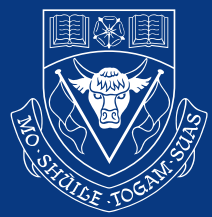

UNIVERSITY OF CALGARY

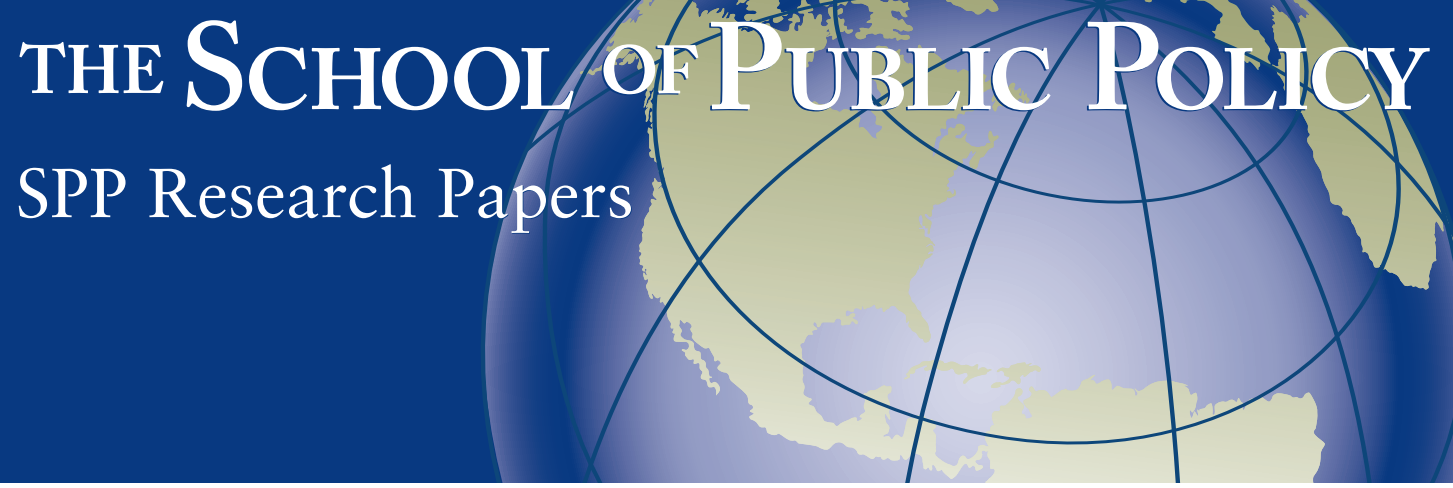

Volume 4 •Issue 7 • May 2011

\title{
SMALL BUSINESS TAXATION: Revamping Incentives to Encourage Growth
}

Duanjie Chen and Jack Mintz*

School of Public Policy, University of Calgary

\footnotetext{
* We wish to thank Matt Krzepkowski for research assistance and David Sewell for helpful editing and his contribution to developing ideas in this paper. We also thank Ron Kneebone and three referees for their detailed comments.
} 


\section{SUMMARY}

This study adopts a new approach in assessing the impact of taxes on small business growth and suggests the need to consider new incentives that would be more effective in encouraging small business growth and would also improve the neutrality of the existing tax system.

In recent years, federal and provincial governments have provided various corporate tax incentives to small businesses with the aim of helping them grow. While it is commonly believed that small businesses are responsible for most job creation, unfortunately the only study available has shown that while many small businesses are created, few grow. Yet many governments believe that the incentives are important even though little evidence supports the effectiveness of small business corporate concessions. Some provinces have actually eliminated corporate taxes on small businesses or reduced such taxes to a symbolic level (e.g., one to two percent) without there being any empirical support in favour of the effectiveness of such actions.

In contradiction to the widely held view that small business tax concessions encourage growth, such small business tax relief could actually be antithetical to growth by creating a "taxation wall." First, it could result in the breakup of companies into smaller, less efficient-sized units in order to take advantage of tax benefits even if there are economic gains to growing in size. Second, it could encourage individuals to create small corporations in order to reduce their personal tax liabilities rather than grow companies. And third, it could lead to a "threshold effect" that holds back small business from growing beyond the official definition of "smallness," regardless of the criteria for measuring size (e.g., the size of revenue or assets, or the number of employees).

In this paper, we evaluate the impact of both corporate and personal taxes on the growth of small business and we focus in particular on the likely consequences of the aforementioned threshold effect. We use a new approach in assessing the impact of taxes on small business growth by estimating the amount of tax paid on the rate of return to capital as a small business grows in size. We show that small business growth is hampered by the existing tax system. As a business grows, effective tax rates on capital investments made by entrepreneurs virtually double when the business grows from as a little as $\$ 1$ million to over $\$ 30$ million in asset size. The issue is particularly important to the provinces that have been creating greater gaps between large and small business tax rates.

The aim of tax incentives should be to try to avoid creating a wall that inhibits growth in small businesses, but instead flattens corporate and personal taxes with respect to incentives structured to induce growth. We provide some specific recommendations for growth-enhancing incentives that are superior to the small business tax deduction and other incentives of a similar type. Incentives associated with size should be avoided as much as possible, a proposal that is consistent with International Monetary Fund (IMF) recommendations. 


\section{INTRODUCTION}

Canadian governments should be praised for their coordinated efforts in reforming our business tax system. This reform has significantly improved tax neutrality across industries for large firms mainly through unifying and lowering corporate income tax rates, eliminating the capital tax, harmonizing sales taxes and better matching the capital cost allowance with the economic depreciation rate.

One of the underlying goals of the aforementioned reforms is to neutralize the tax distortion between corporations of different sizes. The Technical Committee on Business Taxation (hereafter the Mintz Committee) pointed out that a variety of preferential tax measures towards small business "represent a notable departure from a neutral tax system, and give Canadianowned smaller corporations one of the most favored income tax regimes in the world relative to the general tax system." The Mintz Committee suggested that "it may be more appropriate to reduce the general corporate tax rate (and thus the differential between the effective general and small business rates) rather than increasing the amount of income to which reduced federal and provincial rates apply," because reducing the general tax rate "would both reduce existing distortions and incentives for tax planning associated with the small business deduction and improve incentives to invest in business generally."

Unfortunately, tax changes in recent years with respect to small businesses deductions did not heed the advice from the Mintz Committee. Over the past decade, both the federal and provincial governments have more than doubled the income threshold for the small business deduction from $\$ 200,000$ to $\$ 500,000$ (on an inflation-adjusted basis from $\$ 350,000$ to $\$ 500,000)$. These changes took place despite the Mintz Committee's view that "a higherincome threshold would not be consistent with the focus on assisting truly small businesses" because "over 80 percent of small businesses (that claimed the tax deduction) earn less than $\$ 100,000$ in income." Furthermore, some provinces have reduced the tax rate for small business more aggressively than they have reduced the general corporate income tax rate. Among the latter provinces, Prince Edward Island reduced the tax rate for small business to one percent but did nothing for larger businesses, and Manitoba eliminated the tax for small business completely (see Table 1 below). British Columbia has poposed to reduce the provincial small business tax rate to zero. As a result, the tax distortion between large and small firms in these provinces has worsened.

The main argument for taxing small businesses more favourably is to compensate for their limited access to capital financing - a disadvantage often attributed to market failure. Other supporting arguments include excessive compliance costs and cash flow concerns facing small business. But tax measures in general are not an effective remedy for non-tax disadvantages incurred by any long-term business undertaking. More specifically, as suggested in a recent Organization for Economic Cooperation and Development (OECD) study, "preferential

1 Canada: Technical Committee on Business Taxation, Report, 1997, Ottawa: Finance Canada (available at www.fin.gc.ca), Chapter 5 .

2 See Asa Johansson, Christopher Heady, Jens Arnold, Bert Brys and Laura Vartia, "Tax and Economic Growth," OECD, ECO/WKP(2008)28. 
tax treatment of or exemptions from corporate taxation for small firms are not likely to be justified." This is because

investment decisions of small firms do not appear to be more sensitive to corporate taxes than those of large firms - indeed evidence points to the opposite...Thus, special tax reliefs based on firm size could result in economic inefficiencies as resources may be wasted. Cutting back on these exemptions frees resources for cuts in the overall statutory corporate tax rate, which were found to be beneficial for enhancing economic growth by favouring high return and rapidly catching up firms and industries.

In contradiction to the widely held view that small business tax concessions encourage growth, such small business tax relief could be antithetical to growth for three reasons.

First, it could result in the breakup of companies into smaller ones in order to take advantage of tax benefits, which results in giving up economic gains from growing in size to take advantage of economies of scale. While there are "associated corporation rules" that require the small business deduction to be allocated among corporations jointly owned, many circumstances enable companies to break up to take advantage of low corporate tax relief. ${ }^{3}$ This leads to less efficient companies operating in the economy. A recent paper suggests that one of the factors explaining Canada's low rate of productivity compared to the United States is that the Canadian distribution of firms is skewed more to small size. ${ }^{4}$

Second, many small business are created to enable individuals to reduce personal tax rather than grow companies - the small business tax relief thereby distorts the choice between corporate and unincorporated business organization even though some compliance and administrative costs are incurred to operate in the corporate form. With corporate organization, it is easier to split income among family members holding shares of a corporation. Also, income reinvested in the corporation is taxed at preferential rates compared to partnership and sole proprietorships whose income is fully taxed as personal income earned by the owner. One of the few studies focused on this issue showed that the corporate tax imposes much higher economic costs by distorting decisions with respect to the choice of organizational form. ${ }^{5}$ While earlier results would suggest that the distortionary cost of corporate taxation per dollar of revenue is in the five to 13 cent range, the efficiency costs estimated by Gravelle and Kotlikoff are between 84 cents and $\$ 1.51$ of corporate revenues for similar parameter values.

Third, the well known problem with preferential tax treatment targeting small business, regardless of the criteria for defining smallness, is its negative "threshold effect" on growth. That is, whether smallness is defined by the size of assets, revenue or taxable income, or the number of employees, there is always a point beyond which the beneficiary firm may stop growing simply to preserve the tax savings associated with the definition of smallness.

3 See V. Pinero, "Whatever Partnerships Do.... Joint Ventures do Better," mimeograph, 2011.

4 The analysis suggests that 20 percent of the Canadian-US difference between sales per employee is explained by the greater small business sector in Canada. D. Leung, C. Mez, Y. Terajima, "Productivity in Canada: Does Firm Size Matter?" Bank of Canada Review, Autumn, 2008, 5-14.

5 J. Gravelle, J. and L. Kotlikoff, "The Incidence and Efficiency Cost of Corporate Taxation when Corporate and NonCorporate Forms Produce the Same Good,” WP/88/32, Washington D. C. International Monetary Fund, 1988. 
In dealing with this threshold effect, developed countries have taken different approaches. In contrast to Canada, where governments have raised the income threshold for the small business deduction, all the other 11 OECD countries except the United Kingdom that tax small business favourably set an income threshold much lower than that in Canada. ${ }^{6}$ Among these other OECD countries, Luxembourg and the United Kingdom have raised the small business tax rate to shrink the rate gap between small and large firms, which is also in contrast to many Canadian provinces that reduced their tax rates for small business faster than for large firms. In fact, some researchers in the UK strongly advocate the removal of the reduced tax rate for small business, for which they see little economic justification. ${ }^{8}$ Since 2000 , federal reductions in the general corporate tax rate in Canada have reduced the difference between large and small business tax rates.

In this paper, we evaluate the impact of both corporate and personal taxes on the growth of small businesses and we focus in particular on the likely consequences of creating a "taxation wall" that impedes economic growth. We use a new approach in assessing the impact of taxes on small business growth by estimating the amount of tax paid on the rate of return to capital as a small business grows in size. We will show below that small business growth is hampered by the existing tax system. As a business grows, effective tax rates on capital investments made by entrepreneurs virtually double when the business grows from as a little as $\$ 1$ million to over $\$ 30$ million in asset size. This is not unlike the "taxation wall" in the personal income tax system whereby individuals who choose to work more face higher marginal tax rates that undermine their incentive to earn higher income. The question we ask is how to deal with this "taxation wall?" Should we remove it completely or relocate it to encourage more businesses to stay within the "wall?"

Despite claims that small businesses are responsible for much job creation, there are few studies to support such claims. One Canadian study in 1997 showed that only 12 percent of small businesses grew from having less than five employees to 5-19.9 employees and only one percent grew to having more than 20 employees from 1985 to $1992^{10}$ despite the large number of small business corporations created during that time. In our view, it is critical that the federal and provincial governments should undertake the equivalent of a "tax expenditure" analysis to determine the effectiveness of current incentives to small business since so little evidence is available to support them.

Our analysis questions the effectiveness of the small business deduction and other small business incentives in addressing growth. Instead, we find that the incentives undermine the neutrality of the overall tax system and the tax goals of simplification, economic efficiency and fairness.

6 For an early review of small business tax incentives, see Duanjie Chen, Frank Lee and Jack Mintz, "Taxation, SMEs and Entrepreneurship," Organization of Cooperation and Development, STI Working Paper 2002/9, Paris, France, 2002.

7 Refer to OECD Tax Database (www.oecd.org), Tables II.1 and II.2, for more details.

8 See for instance, Claire Crawford and Judith Freedman, "Small Business Taxation, A Special Study of the Structural Issues Surrounding the Taxation of Business Profits of Owner Managed Firms," 6th August 2008, http://www.ifs.org.uk/mirrleesreview/press_docs/small_businesses.pdf.

9 The federal and provincial governments have eliminated most capital taxes that also favoured small businesses.

10 See K. Hendricks, R. Amit and D. Whistler (1997), Business Taxation of Small and Medium-sized Enterprises in Canada, Department of Finance Working Paper 97-11, Government of Canada, Ottawa and Report of the Technical Committee on Business Taxation (Finance Canada, Ottawa, 1997) p. 5.2. 
While specific incentives for small business simply complicate the tax system, policy may still be used to address concerns regarding the difficulty small businesses have in tapping credit and stock markets relative to the ease with which large multinationals obtain funds. ${ }^{11}$ Tax incentives should focus on growth, not on creating barriers to growth. A recent report by the IMF suggests: “...the best response to market failures that may adversely affect [small medium enterprises] is unlikely to be through size-related tax measures." 12 We concur with that view.

One example would be the expensing of capital up to a limit for all businesses to encourage growth through investment. Such an incentive would offer more benefits to smaller companies that want to grow rather than those whose principal purpose is to reduce personal income taxes on business income. A second reform would be to introduce capital gains tax relief for companies that go public, an incentive used in the US to grow companies (to be discussed in more detail later). A third measure would be to broaden existing measures to reduce the lock-in effect of capital gains taxes so as to allow entrepreneurs and investors to replace existing assets with new ones on a deferral basis. We recommend a formal capital gains deferral account similar to that proposed by Mintz and Wilson. ${ }^{13}$

The rest of this paper is structured in four sections. We first outline the types of incentives used in the tax system for small business investment in Canada. This is followed by a description of the basic model used to estimate the impact of taxes on small business investment. We then apply this model to an examination of the impact of corporate and personal taxes on the incentive for entrepreneurs to invest in small businesses as they grow in size. This examination is enriched by simulations of various business scenarios (e.g., different profit ratios, debt-toasset ratios and dividend payout ratios). The final section discusses policy implications of our analysis and concludes with policy recommendations.

\section{SMALL BUSINESS TAXATION IN CANADA}

For decades, Canada has provided a special tax regime for small business to relieve them of taxes to be paid to federal and provincial governments. The legal form of "small business" that qualifies for small business deduction is Canadian-controlled private corporations (CCPC). Under the small business deduction (hereafter SBD), a CCPC is entitled to a reduced corporate income tax rate on its first $\$ 500,000$ of active business income if its "taxable capital," as defined under the federal Income Tax Act (Part I.3), does not exceed \$10 million. The federal SBD is reduced progressively on a straight-line basis for CCPCs when their taxable capital increases from $\$ 10$ million to $\$ 15$ million and no SBD is available once their "taxable capital" exceeds $\$ 15$ million. Most of the provinces have provided similar treatment for small business although corporate rates and thresholds differ by province. In the case of Ontario, the surtax on small business income above the threshold (a clawback of the small business deduction) was eliminated in the 2009 Budget. Table 1 provides a summary of the statutory corporate income tax rate and corresponding income threshold for SBD in years 1997, 2005, 2008 and 2010.

\footnotetext{
11 According to Claire Crawford and Judith Freedman (note 8), there is no evidence of any general capital market failure in the UK, and the principal finance gap is for new and start-up businesses rather than small businesses.

12 International Tax Dialogue, "Taxation of Small and Medium Businesses," prepared by staff of the IMF with input from staff of the other organizations participating in the ITD (the Inter-American Development Bank, OECD and World Bank), October 2007.

13 Jack Mintz and Thomas A. Wilson, "Removing the Shackles: Deferring Capital Gains Taxes on Asset Rollovers," C.D. Howe Institute Backgrounder, Toronto: C.D. Howe Institute, April, 2006.
} 
Further reductions in the general corporate tax rate will occur at the federal level by 2012 with the difference between the large and small business rate being 15 and 11 percent respectively.

As shown in Table 1, the trend in many provinces is that the SBD has become more and more generous with the reduced tax rate being further reduced and the income threshold for such reduced tax rates being more than doubled. While the federal government and a few provinces attempted to strike a balance by cutting the general corporate tax rate more aggressively than that for small business, many provinces went to the other extreme to dramatically reduce (e.g., PEI) or eliminate the tax rate for small business entirely (e.g., Manitoba by 2012).

Against the trend of enhancing the SBD in many cases, New Brunswick reversed such enhancement in its sweeping tax reform of 2008. The 2008 tax reform introduced a plan for reducing the general corporate income tax rate from 13 percent to eight percent by 2012 and keeping the reduced rate of five percent for small business (which is partially restored from the $1.5 \%$ rate that applied in 2007) unchanged. Although the current New Brunswick government now plans to only reduce the corporate tax rate to 10 percent and to reintroduce the tax reduction for small business, the gap between the two rates narrows from 11 percentage points in 2005 to five percentage points for 2011, which is the least for all provinces except for Quebec. In Quebec, this rate gap is under four percentage points but there was no such rate gap back in 2005.

TABLE 1: Small Business Deduction (SBD): Tax Rate and Revenue Threshold*

\begin{tabular}{|c|c|c|c|c|c|c|c|c|c|}
\hline & \multicolumn{5}{|c|}{ Corporate income tax rate (\%): reduced vs. general } & \multicolumn{4}{|c|}{$\begin{array}{l}\text { Revenue threshold } \\
(\mathbf{\$ 0 0 0 )} \text { for SBD }\end{array}$} \\
\hline & 1997 & 2005 & 2008 & 2010 & $\begin{array}{l}\text { Change in } \\
\% \text { point }\end{array}$ & 1997 & 2005 & 2008 & 2010 \\
\hline Federal & 13.12 / 29.12 & $13.12 / 22.12$ & $11 / 19.5$ & $11 / 18$ & $-2.1 /-11.1$ & $\$ 200$ & $\$ 300$ & $\$ 400$ & $\$ 500$ \\
\hline NFLD & $5 / 14$ & $5 / 14$ & $5 / 14$ & $4 / 14$ & $-1 / 0$ & $\$ 200$ & $\$ 300$ & $\$ 400$ & $\$ 500$ \\
\hline P.E.I. & $7.5 / 16$ & $6.5 / 16$ & $3.2 / 16$ & $1 / 16$ & $-6.5 / 0$ & $\$ 200$ & $\$ 300$ & $\$ 400$ & $\$ 500$ \\
\hline N.S. & $5 / 16$ & $5 / 16$ & $5 / 16$ & $5 / 16$ & $0 / 0$ & $\$ 200$ & $\$ 350$ & $\$ 400$ & $\$ 400$ \\
\hline N.B. & $7 / 17$ & $2 / 13$ & $5 / 13$ & $5 / 11$ & $-2 /-6$ & $\$ 200$ & $\$ 450$ & $\$ 400$ & $\$ 500$ \\
\hline QUE. & $5.91 / 9.15$ & $8.9 / 8.9$ & $8 / 11.9$ & $8 / 11.9$ & $+2.1 /+2.8$ & $\$ 200$ & $\$ 400$ & $\$ 400$ & $\$ 500$ \\
\hline ONT. & 9.5 / 15.5 & $5.5 / 14$ & $5.5 / 14$ & $4.5 / 12$ & $-5 /-3.5$ & $\$ 200$ & $\$ 400$ & $\$ 500$ & $\$ 500$ \\
\hline MAN. & $9 / 17$ & $5 / 15$ & $2 / 13$ & $0 / 12$ & $-9 /-5$ & $\$ 200$ & $\$ 400$ & $\$ 400$ & $\$ 400$ \\
\hline SASK. & $8 / 17$ & $5 / 17$ & $4.5 / 12$ & $4.5 / 12$ & $-2.5 /-5$ & $\$ 200$ & $\$ 300$ & $\$ 500$ & $\$ 500$ \\
\hline ALTA. & $6 / 15.5$ & $3 / 11.5$ & $3 / 10$ & $3 / 10$ & $-3 /-5.5$ & $\$ 200$ & $\$ 400$ & $\$ 460$ & $\$ 500$ \\
\hline B.C. & $9 / 16.5$ & $4.5 / 12$ & $2.5 / 11$ & $2.5 / 10.5$ & $-6.5 /-6$ & $\$ 200$ & $\$ 400$ & $\$ 400$ & $\$ 500$ \\
\hline YUKON & $6 / 15$ & $4 / 15$ & $4 / 15$ & $4 / 15$ & $-2 / 0$ & $\$ 200$ & $\$ 400$ & $\$ 400$ & $\$ 400$ \\
\hline N.W.T. & $5 / 14$ & $4 / 14$ & 4 / 11.5 & $4 / 11.5$ & $-1 /-2.5$ & $\$ 200$ & $\$ 300$ & $\$ 400$ & $\$ 500$ \\
\hline NUV & NA & $4 / 12$ & $4 / 12$ & $4 / 12$ & $0 / 0$ & NA & $\$ 300$ & $\$ 400$ & $\$ 500$ \\
\hline
\end{tabular}

* Effective at the end of year. According to the latest budget plans, by 2012, the federal general corporate income tax rate will fall to 15 percent (the small business rate remains 11 percent resulting in a 4-point spread). The Ontario general corporate income tax rate falls to 10 percent (the small business rate will be 5.5 points below that). The New Brunswick general corporate income tax rate will fall to 10 percent and small business rate to 4.5 percent. The small corporate income tax rate will be further reduced to four percent in Nova Scotia (11 points below the general rate), $2.5 \%$ in Saskatchewan (9.5 points below the provincial general rate) and possibly zero in BC (10 points below the provincial general rate).

Sources:

1. Deloitte, Corporate income tax rates, 2005-2012 (updated to January 31, 2010).

2. PriceWaterHouseCoopers, Tax Facts and Figures: Canada 2010.

3. Ernst \& Young, Tax Alert, http://www.ey.com/CA/en/Services/Tax/Tax-Alerts

3. For New Brunswick, http://www.gnb.ca/0024/tax/index.asp

4. For 1997, Report of the Technical Committee on Business Taxation, page 2.2. 
Besides the small business deduction related to taxing income at the firm level, the other two main components of the small business tax regime are related to taxation of dividends and capital gains from small business within personal income taxation.

- Dividend Taxes: The dividend tax rate varies by income and credit rate. Investors pay personal income tax on dividends but are given a dividend tax credit as an offset for corporate taxes deducted from profits. Therefore, the purpose of the dividend tax credit given to shareowners of a corporation is to compensate them for the corporate tax deducted from profits prior to the distribution of dividends. Under the dividend tax credit regime in Canada, a low dividend tax credit is provided for "ineligible" dividends distributed from earnings taxed at the reduced business tax rate while a high dividend tax credit is provided for "eligible" dividends paid from profits subject to the general corporate income tax rate. When the corporation grows in asset size or earns more profits, its corporate income tax rate jumps. This higher corporate income tax rate is offset by a larger dividend tax credit given to the shareholders, resulting in a lower personal tax on dividends. This implies that the personal income tax rate on dividends shifts down when a small business expands and moves from paying a low to a high corporate income tax rate.

- Lifetime Capital Gains Exemption: The first \$750,000 of capital gains on qualifying shares held in Canadian-controlled businesses (as well as capital gains from farm and fishing property) is exempt from personal income tax (there is no explicit limit on firm size but most CCPCs are small companies). Thus, as a business grows, the entrepreneur is subject to capital gains tax when the business becomes sufficiently large to exceed this threshold. Since capital gains taxes are applied when shares are sold (rather than as gains accrue), we shall calculate an accrual-equivalent capital gains tax rate under the assumption that shares in small businesses are on average held for 20 years. To the extent that shares are held for fewer (more) years, the accrual-equivalent capital gains tax rate is higher (lower). If the accrual-equivalent capital gains tax rate is higher in value, the impact of the lifetime capital gains exemption becomes more severe in impeding growth.

The above three aspects of the tax system-the small business deduction, dividend taxes and the lifetime capital gains exemption-are modeled. There are other tax provisions listed in Appendix A that also provide benefits to small businesses but are not incorporated in the model at this point primarily due to lack of data. These include the following:

- A research and development credit that is richer for small CCPCs compared to large ones. Small firms are provided a federal credit equal to 35 percent of research and development expenditure while larger companies are provided a lower credit equal to 20 percent of such expenditure. Further, the higher credit rate for small businesses is phased out between $\$ 10$ million and \$50 million in expenditures. Similar to the small business tax deduction, the differential credit rates also act as a "taxation wall" for innovative companies.

- Capital gains deferral for entrepreneurs selling firms so long as proceeds are reinvested in another small business.

- Special personal tax provisions for CCPCs with respect to the deduction of losses on the disposal of shares and favourable treatment of capital gains on stock options. Similar to the lifetime capital gains exemption that apply to all CCPCs, these provisions are not explicitly limited to thresholds related to firm size, but primarily benefit small businesses that make up the majority of CCPCs. 
- Tax relief measures under the federal Goods and Services Tax (GST) and Harmonized Sales Tax (HST) that exempt companies with less than $\$ 30,000$ in sales from collecting such taxes and the Quick Method for remitting GST and HST sales taxes (allowing small business to keep some of the revenue in lieu of claims for input tax credits).

- An exemption below a specified payroll ceiling from provincial payroll taxes.

In the case of the latter two incentives, they would not be relevant to the decision to invest in capital, but they do impact on employee hiring and production decisions. Our model focuses on the investment incentives.

\section{A MODEL TO ESTIMATE THE IMPACT OF TAXATION ON SMALL BUSINESS GROWTH}

Most recent studies of business taxation in Canada have focused on multinational companies, which are assumed to raise capital in international markets. ${ }^{14}$ In these studies, personal tax rates paid by Canadians have a negligible impact on the cost of debt and equity financing since Canada only accounts for a small share of such capital raised in international markets.

In the case of small business, entrepreneurs provide the major source of equity finance for their small business and typically obtain debt finance from lending institutions. Thus personal taxes on entrepreneurial income (dividend and capital gains taxes), and not just corporate income taxes, play a significant role in affecting the cost of financing raised by small business. On the other hand, banks and other financial lenders to small business operate on an international scale so that personal taxes have little effect on the interest rate charged on debt finance raised in international credit markets.

The marginal effective tax rate (METR) calculated for this study is based on an entrepreneur investing his savings in the equity of the business (it is assumed that debt is provided by banks and other lending institutions). It is calculated as the difference between the pre-tax rate of return on capital and the net of corporate and personal tax of return on capital. The entrepreneur will invest in equity until the after-tax rate of return on incremental investment is equal to the net-of-tax return that could be earned on alternative investments, adjusted for risk. The cost of debt finance is the interest rate charged in the market for debt as provided by banks and other lenders. See Appendix C for an elaboration of the model's theoretical analysis.

For example, ignoring debt finance, if the pre-tax (net-of-risk) rate of return on capital is 10 percent and the corporate tax rate is 20 percent, the profit rate to owner, net of corporate taxes, is eight percent. If the personal tax rate on profits derived from the business is 30 percent, the net-of-tax rate of return on investment is equal to 5.6 percent $(8(1-0.3)=5.6)$. If the after-tax return on equity is sufficiently high so as to reward the entrepreneur for investing in the business rather than in other opportunities (after netting out risk), the project will be undertaken.

14 Chen, Duanjie and Jack Mintz, Canada's Tax Competitiveness After A Decade of Reforms Still an Unfinished Plan, The School of Public Policy, SPP Papers, May 2010, http://policyschool.ucalgary.ca/files/publicpolicy/TaxCorp.pdf and Finance Canada, Tax Expenditures and Evaluations 2008, Part 2 - Research Report: Considerations in Setting Canada's Corporate Income Tax Rate, http://www.fin.gc.ca/taxexp-depfisc/2008/taxexp08_4-eng.asp\#Considerations. 
When the METR is calculated for the entrepreneur, the annualized value of corporate taxes (the corporate income tax rate and provisions for cost deductions, sales taxes on capital purchases and capital-based taxes) and personal tax on equity income (personal income taxes on dividends and capital gains) is calculated as a percentage of the pre-tax return earned on investments. In other words, an entrepreneur is responsible for paying taxes at both the firm level and the personal level, all of which contribute to the tax wedge or METR on small business.

The METR on entrepreneurial investments in small business is estimated below as a business grows in asset size. For example, with a given pre-tax profit rate and a given dividend payout ratio, as dividends increase along with capital size and revenue, the personal tax rate on dividends rises. When either the capital or taxable income crosses the threshold defining the SBD, the corporate income tax rate rises and the personal tax rate on dividends shifts down. In the model, we also assume financial policies do not change as a small business grows. If they do change, it would have tax and non-tax effects on profitability, but at the margin will not impact the overall cost of capital. However, it is possible that businesses facing a higher corporate income tax rate might choose financial policies to avoid its impact, which is not explicitly modeled below.

In calculating METR for small business, compared to that for large firms, several assumptions warrant special attention.

First, the debt-to-asset ratio for small business is assumed to be much lower than that used for large firms. Based on statistics for non-financial firms with annual revenue under $\$ 5$ million, the debt-to-asset ratio assumed for small firms is about 29 percent (Appendix B). This is far lower than the 40 percent debt-to-asset ratio assumed in our study of large firms. The underlying fact is that, in general, the smaller the firm, the lower the debt-to-asset ratio. This lower debt-to-asset ratio could be a result of weaker borrowing power by small firms or fewer corporate tax benefits arising from increased interest deductions associated with leverage.

Second, the assumption for the pre-tax profit ratio (profits divided by assets) is critical to calculating METR for small business but irrelevant to that for large firms. This is because under the SBD, the reduced corporate income tax rate is restricted to firms having certain capital and revenue sizes. For a given capital size for SBD, only a given pre-tax profit ratio makes it possible to gauge which tax rate-the general one or the reduced one-should be used in the model. That is, our model is first set up based on capital size, which, when combined with a pre-tax profit rate, gives taxable income based on which the tax rate can be assigned. Again, based on the Statistics Canada data (Appendix B) available to us, the average pre-tax profit rate for non-financial firms with revenue under $\$ 5$ million was five percent in 2004-6. This five percent pre-tax profit rate is assumed as the base case for our calculation. Simulations for different profit rates will be presented later. 


\section{THE THRESHOLD EFFECT ON METR FOR SMALL BUSINESS}

The threshold effect arising from the preferential tax treatment for small business is commonly observed as a turning point in the tax impact on firm growth. In the case of Canada's SBD, the threshold is $\$ 500,000$ in taxable income, or $\$ 10$ million in "taxable capital," whichever threshold is exceeded first. The lifetime capital gains exemption introduces another threshold as equity investment by the entrepreneur in the company grows in value as the firm increases in size. These threshold effects can be illustrated by our METR calculation.

The base case in our METR model is assumed to have a five percent pre-tax profit ratio, a 29 percent debt-to-asset ratio and a 40 percent dividend payout ratio for 2010. Figure 1 presents the Canada-wide average METR for small business as a base case, and Figure 2 further provides the 10 provincial counterparts to the base case. Figure 3 simulates the average Canada-wide METR with different income thresholds for SBD ranging from $\$ 200,000$ (the 1997 level) to $\$ 500,000$ (the level since 2009) to see whether such variation has helped alleviate the threshold effect. And Figures 4-6 provide further simulations by varying the pretax profit rate, the dividend payout ratio and the debt-to-asset ratio, respectively.

\section{A. The Canada-Wide Pattern}

As Figure 1 shows, with a pre-tax profit ratio of five percent, the METR on a small business jumps after capital size exceeds $\$ 10$ million, corresponding to which capital size the taxable income exceeds $\$ 500,000$ - the revenue threshold for the SBD. At this turning point, the METR is 27.5 percent.

Below this threshold, the METR rises gradually (from the low of 18 percent) as dividends paid to the owner grow. This rise in the METR especially at low asset values results from income becoming subject to higher personal taxes under the progressive tax rate structure. Other tax factors contributing to the gradual upward creep in the METR include the existing residual provincial capital taxes that kick in at different levels of total assets (e.g., \$2 million in Quebec and $\$ 6$ million in Nova Scotia) and the lower income threshold (i.e., $\$ 400,000)$ for SBD in Manitoba and Nova Scotia (see below in Figure 2). The provincial capital taxes will all be eliminated by 2012 .

After the turning point with the 27.5 percent METR, the national METR on small business jumps by almost eight percentage points to 35.3 percent. While the higher dividend tax credit rate mitigates the impact of a higher corporate income tax rate, retained profits are subject to higher corporate taxes when the corporation grows beyond $\$ 10$ million in asset size. This higher METR of 35.3 percent stabilizes until the capital size reaches $\$ 36$ million, when small business exhausts its lifetime exemption for $\$ 750,000$ in capital gains and hence will pay capital gains tax. The capital gains tax rate at this point is assumed to be the top personal capital gains tax calculated on an accrual basis, which contributes to a jump in the METR by seven percentage points. These calculations are sensitive to the holding period for shares and can be influenced by the time it takes for the investor to exhaust the lifetime capital gains exemption. The calculation is based on a 20-year holding period for shares-a lower holding period leads to a higher capital gains tax rate and therefore a higher METR. The calculations also depend on an assumption that only one entrepreneur owns the company and the entrepreneur does not own or has not owned other small businesses. Otherwise, the jump in the METR as the lifetime capital gains exemption is exhausted will vary from that for the asset size that we have characterized. 


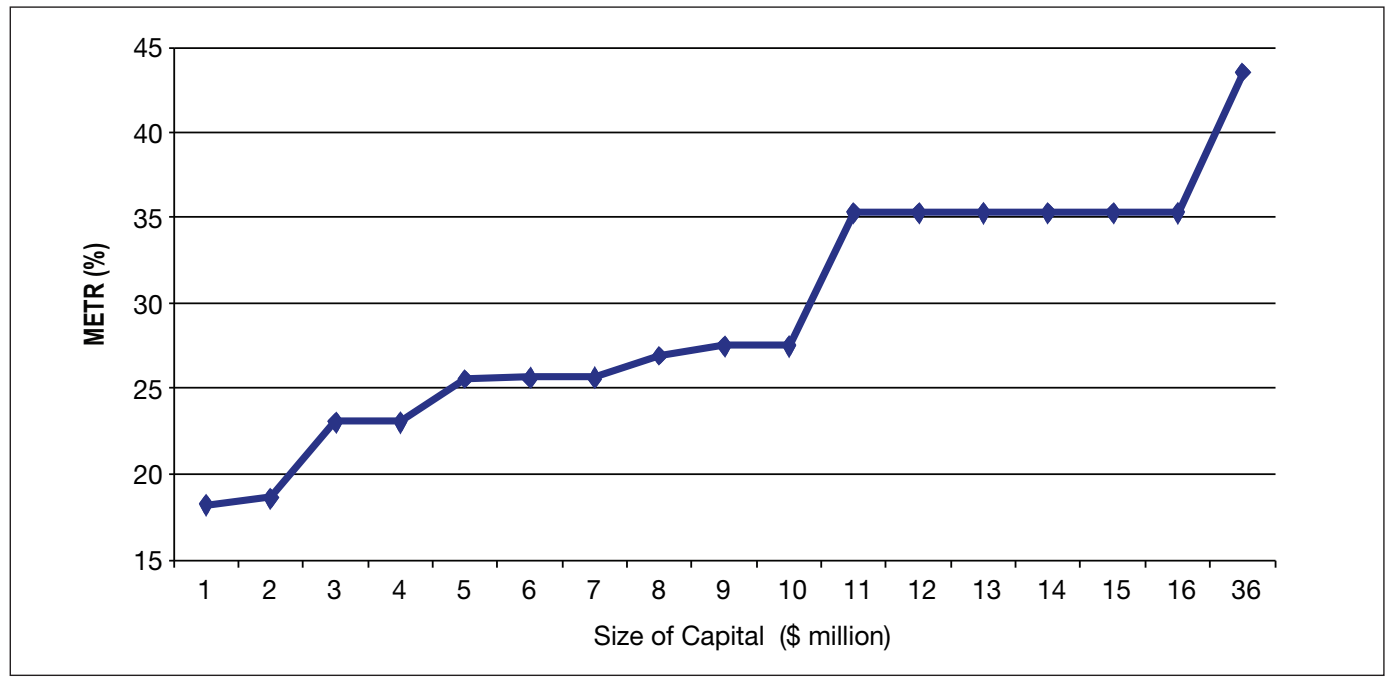

The jump in the METR can be understood as follows. The METR is the wedge between the pre-tax (R) and after-tax (r) rate of return on capital that an investor has to receive to justify making an investment. In symbols:

$$
\begin{aligned}
& \operatorname{METR}=(\mathrm{R}-\mathrm{r}) / \mathrm{R} \text { or } \\
& \mathrm{R}=\mathrm{r} /(1-\mathrm{METR}) .
\end{aligned}
$$

If, for example, investors need a rate of return on five percent ${ }^{15}$ and the METR is 27 percent, the required pre-tax rate of return on capital is 6.85 percent. If the METR becomes 35 percent, the required pre-tax rate of return on capital becomes 7.7 percent. Projects that were acceptable with pre-tax rates of return more than 6.85 percent but less than 7.7 percent would be given up when the firm grows larger. This can deter the growth of businesses.

Given that the majority of small corporations have total assets well below $\$ 1$ million, Figure 1 implies that the threshold effect of the SBD hinders a minority of small firms that invest a relatively large amount of capital, generate a relatively large amount of revenue and hence have a much greater potential to grow their business. On the other hand, the fact that the majority of small business stays extremely small ${ }^{16}$ may have little to do with the objective of growing their businesses, but much to do with tax savings arising from the SBD.

The threshold especially matters when small business owners reinvest their profits, as opposed to when they take out dividends. Given that combined corporate and personal taxes on dividends at the top corporate rate do not deviate far from the corresponding personal tax rates, small businesses that fully payout profits in the form of dividends do not face a large jump in the marginal effective tax rate (refer to Sub-section E and Figure 5 below).

\footnotetext{
15 All rates of return are expressed net of risk costs. The cost of risk is reduced by taxation to the extent governments share losses through carry-back and carry-forward provisions for losses and unused credits.

16 According to Statistics Canada, "the majority of the small corporations (60 percent) deploy under $\$ 300,000$ in total assets.” See L. Pelot, “A Profile of Small Business Across Canada,” Insights on, Vol. 2, No. 3, November 1998. http://www.statcan.gc.ca/pub/61f0019x/61f0019x1997004-eng.pdf.
} 
When small business reinvests profits, owners could take several actions to avoid the higher corporate income tax rate on profits. The owner could take salary income when the threshold is reached with the salary deducted at the corporate level and fully taxed at the personal level. The disadvantage is that the small business becomes more constrained in its available cash flow to finance capital expansion. Alternatively, the owner could lend money to the corporation - the interest payments are deductible at the corporate level although fully taxed at the personal level. This might provide some additional capital for expansion from the owner's personal wealth.

Unfortunately, there are no data available to test for threshold impacts that would arise with asset size or profit limits. To test whether the threshold matters, it would be necessary to evaluate the extent to which dividends and/or salary are paid to owners at the threshold (the jump is then avoided), debt policy (that mitigates the impact of the jump) and the future profits that would be gained from expansion that would encourage the company to grow anyway for non-tax reasons.

\section{B. The Provincial Diversity of METRs on Small Business}

Figure 2 shows the diversity of provincial METRs on small business. With the 5 percent pretax profit ratio, the METR in the majority of provinces shows the threshold effect that arises when asset size exceeds $\$ 10$ million and hence assumed taxable profits exceed $\$ 500,000$. The exceptions are Manitoba and Nova Scotia where the revenue threshold for the SBD is $\$ 400,000$. For these two provinces, the first turning point occurs with an asset size of $\$ 8$ million (and hence assumed profit of $\$ 400,000$ ), after which the provincial corporate income tax rates jump by 12 and 11 percentage points respectively, which contributes to the jump in the METRs by seven and nine percentage points respectively.

FIGURE 2 Marginal Effective Tax Rate on Small Business The Base Case by Province

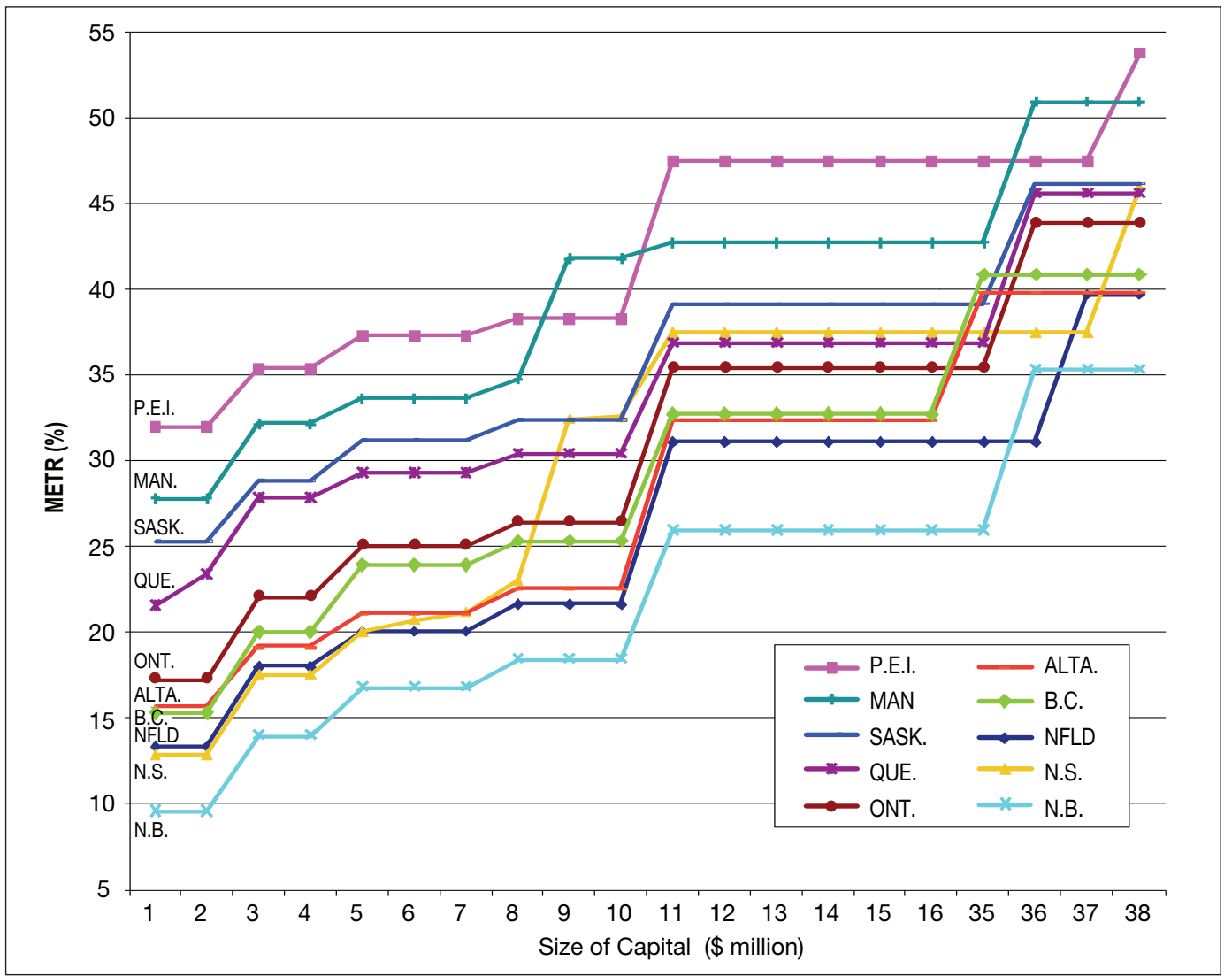


The most intriguing finding from Figure 2 is that Manitoba and PEI, the two provinces with the most generous SBD as implied by the lowest tax rate for small business (zero and one percent respectively), show the highest METR for small business. The reason for such a counter-intuitive outcome is that, despite the generous SBD, the provincial sales tax on capital purchases contributes to a rather high tax cost on capital investment by all firms regardless of their sizes. Saskatchewan appears to be the third-highest taxed province for small business also because of its sales tax on capital purchases. If these three provinces were to follow the other provinces and harmonize their sales taxes with the federal GST, their METR on small business could drop by about 10 to 20 percentage points, which in turn could collectively lower the national average METR on small business by more than one percentage point.

The other three Atlantic provinces (New Brunswick, Newfoundland and Nova Scotia) have the lowest taxes for small business among all the provinces, a result arising from the federal investment tax credit that is available to the Atlantic region.

Among other provinces, the general link between the statutory corporate income tax rate and the METR prevails. That is, given the almost identical tax provisions other than provincial income tax rates, the lower the provincial income tax rate, the lower the METR (e.g., Alberta and $\mathrm{BC})$.

\section{The Variation of Income Thresholds for SBD}

To illustrate the true impact of the recent trend in raising the income threshold to "facilitate" small business growth, Figure 3 provides a variation of our base case with a range of income thresholds from $\$ 200,000$ (which applied pre-2005) to $\$ 500,000$ (since 2009).

FIGURE 3 Marginal Effective Tax Rate on Small Business

Simulation 1: The Base Case with Varying Revenue Ceilings for Small Business Deduction

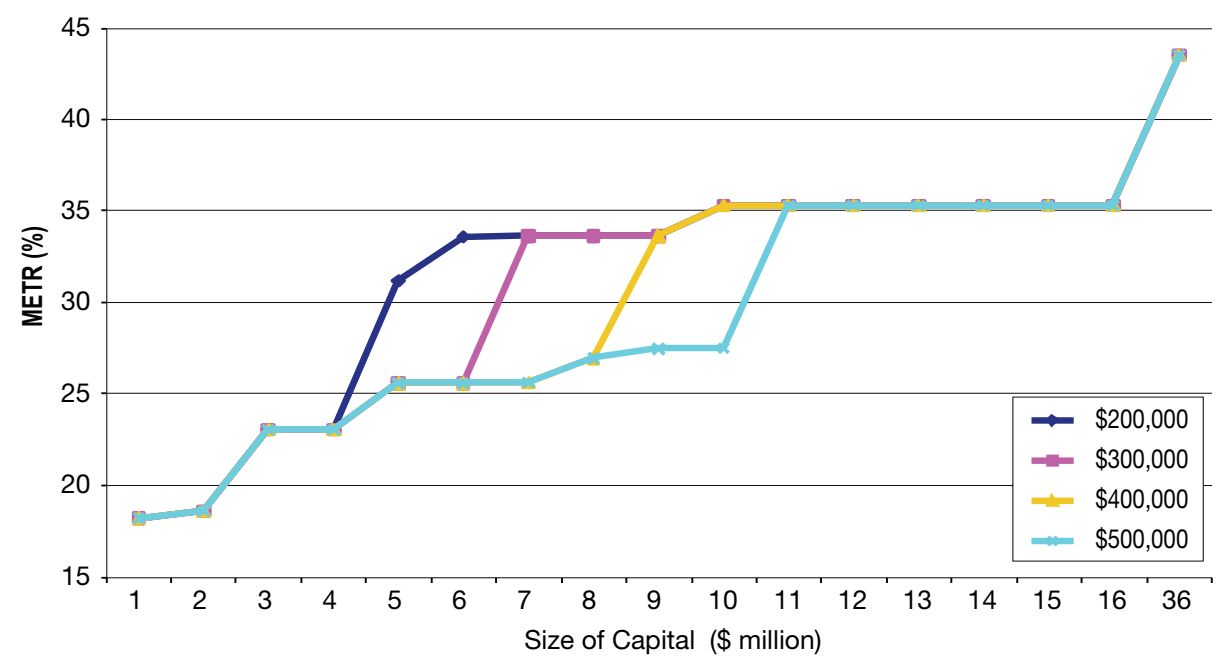


As the figure shows, raising the income thresholds for the SBD does not deal with the threshold effect of the SBD but moves the turning point beyond which the threshold effect incurs. If the purpose is to encourage small business to grow, raising the income threshold does not seem to do the job. Because any given income threshold would always appear to be a curb on growing business by a certain group of small businesses, or at a certain stage of growth for a small firm, a lower threshold curbs growth in lower-income firms and a higher threshold curbs growth of higher-income firms. The threshold effect does not disappear, but the integrity of the tax system is further impaired.

As noted by the Mintz Committee, "over 80 percent of small businesses earn less than $\$ 100,000$ in income" and "many small corporations with $\$ 200,000$ or more of annual business profits are owned by wealthy individuals," hence the Mintz Committee's conclusion that the fairness of raising revenue ceilings blindly "would be questionable." More importantly, "increasing the small business limit would introduce additional non-neutralities and distortions into the system."

\section{The Variation of the Pre-Tax Profit Rate}

One of the arguments for raising the income threshold for the SBD is to support highly profitable firms with substantial growth potential. Our simulation will show this argument is unjustified.

As explained earlier, the assumption with respect to the pre-tax profit rate is critical to our calculation of METR on small business. For a given size of assets, the higher the pre-tax profit rate, the sooner a small firm may exceed the income threshold for the SBD and start paying the general and higher corporate income tax rate.

Figure 4 presents four cases, each having pre-tax profit ratios of four percent, five percent, six percent and 10 percent, respectively. In the case of a pre-tax profit rate of four percent, the threshold effect will not occur until the firm grows its investment beyond $\$ 12.5$ million and hence earns pre-tax revenue beyond $\$ 500,000$. On the other end of the scale, with a pre-tax profit ratio of 10 percent, the firm will start losing its SBD benefit as soon as its assets exceed $\$ 5$ million (corresponding to pre-tax earnings exceeding $\$ 500,000$ ).

This simulation shows that a higher income threshold preserves the SBD benefit longer for all firms, but more so for less profitable ones (hence those with lower potential for growth). That is, a higher income threshold provides a longer tax advantage for less profitable firms as compared to those that are highly profitable. If profitability indicates growth potential, then it becomes clear that, the higher the income threshold, the longer a slow-growing small business can continue to benefit from the SBD. 
FIGURE 4 Marginal Effective Tax Rate on Small Business

Simulation 2: 29\% Debt-to-Asset Ratio, 40\% Dividend Payout Ratio and Varying Pre-tax Profit-to-Asset Ratios

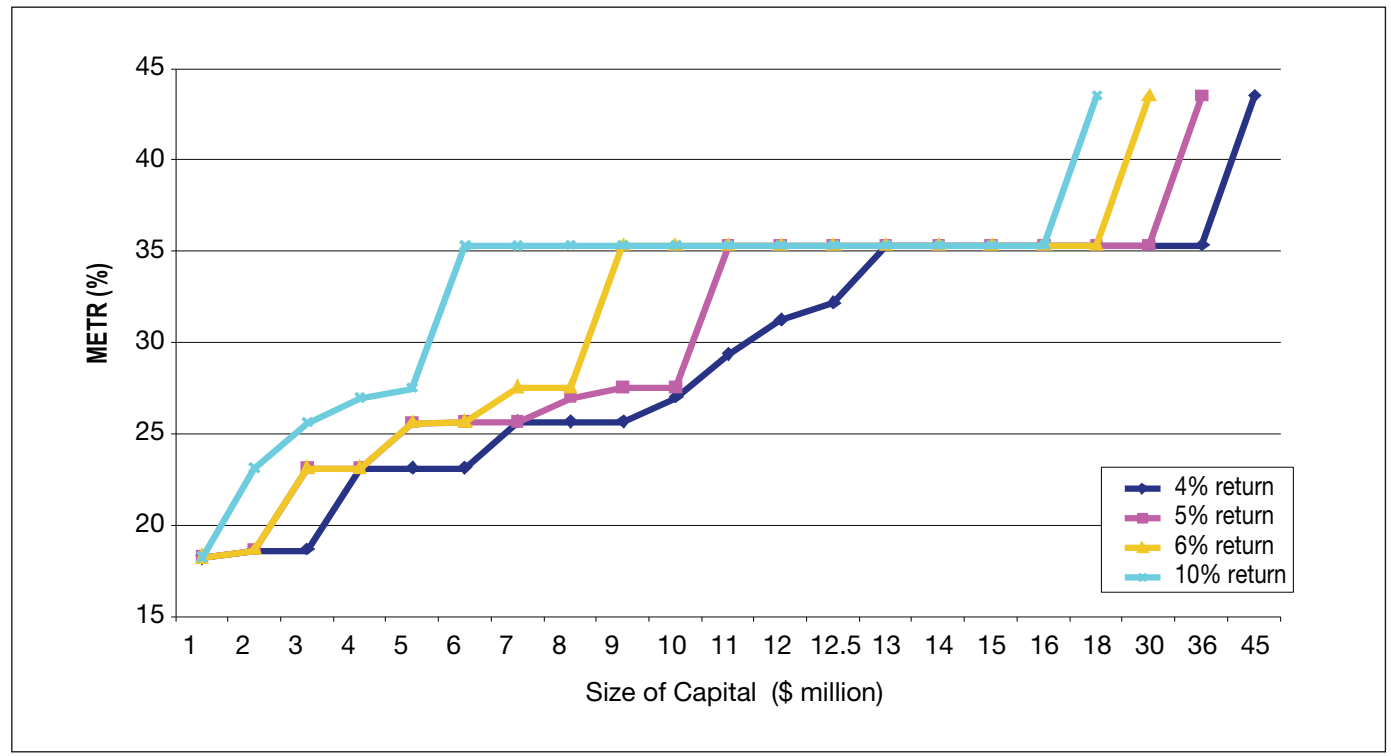

It is also noteworthy that the rule for clawing back the SBD within the asset range of $\$ 10$ million - \$15 million plays a part in determining the METR for slow-growing firms (e.g., with a pretax profit rate of 4 percent). That is, slow-growing firms hit the minimum capital threshold earlier than the income threshold, but the incremental capital threshold kicks in gradually along with the clawback mechanism. Therefore, the threshold effect for slow-growing firms does not appear as steep as that for fast-growing firms.

\section{E. Variation of the Dividend Payout Ratio}

By varying the dividend payout ratio from zero to 100 percent, Figure 5 shows convincingly that the SBD tax system appears to be "pro growth" for small business by taxing their dividends more heavily than their retained earnings. That is, the higher the dividend payout ratio (e.g., 100 percent versus zero percent) and hence the less a firm retains earnings for growing its business, the higher the marginal effective tax rate on the entrepreneur, since dividends are more highly taxed than capital gains that are exempt. But here is the catch: the lower the dividend payout ratio (e.g., zero percent vs. 40 percent) and hence the more a firm retains earnings for growing its business, the earlier the firm will exhaust its lifetime capital gains exemption and start paying capital gains tax, at which point the third threshold effect occurs. Therefore, a small business is faced with a double-edged sword on its path of growth, which also encourages more wasteful tax planning should a principal purpose of setting up a small corporation be to save on taxes.

It is interesting to observe that, with a 100 percent dividend payout ratio, a small business may be highly taxed but with a minimum threshold effect. That is, with the 100-percent payout ratio, when the capital size exceeds $\$ 10$ million and hence profit exceeds the income threshold of $\$ 500,000$, the METR rises only by 2.4 percentage points, the smallest threshold effect from all our METR simulations. This is achieved by the specially designed dividend tax credit 
regime that ensures "ineligible" dividends are more highly taxed than "eligible" dividends. As described earlier, eligible dividends are those distributed from income subject to the general corporate income tax while ineligible dividends are distributed from income subject to the reduced corporate tax rate under the SBD. Obviously, this specially designed dividend tax credit regime is intended to integrate corporate and personal taxes so as to avoid double taxation of dividends that would otherwise occur. However, as usual, such sophisticated and well-intended tax design complicates our tax system and increases administrative and compliance costs for both taxpayers and tax administrators. This tax complication can be avoided by eliminating the SBD so as to tax all corporations equally.

\section{FIGURE 5 Marginal Effective Tax Rate on Small Business}

Simulation 3: 5\% Pre-tax Profit-to-Asset Ratio, 29\% Debt-to-Asset Ratio and Varying Dividend Payout Ratios

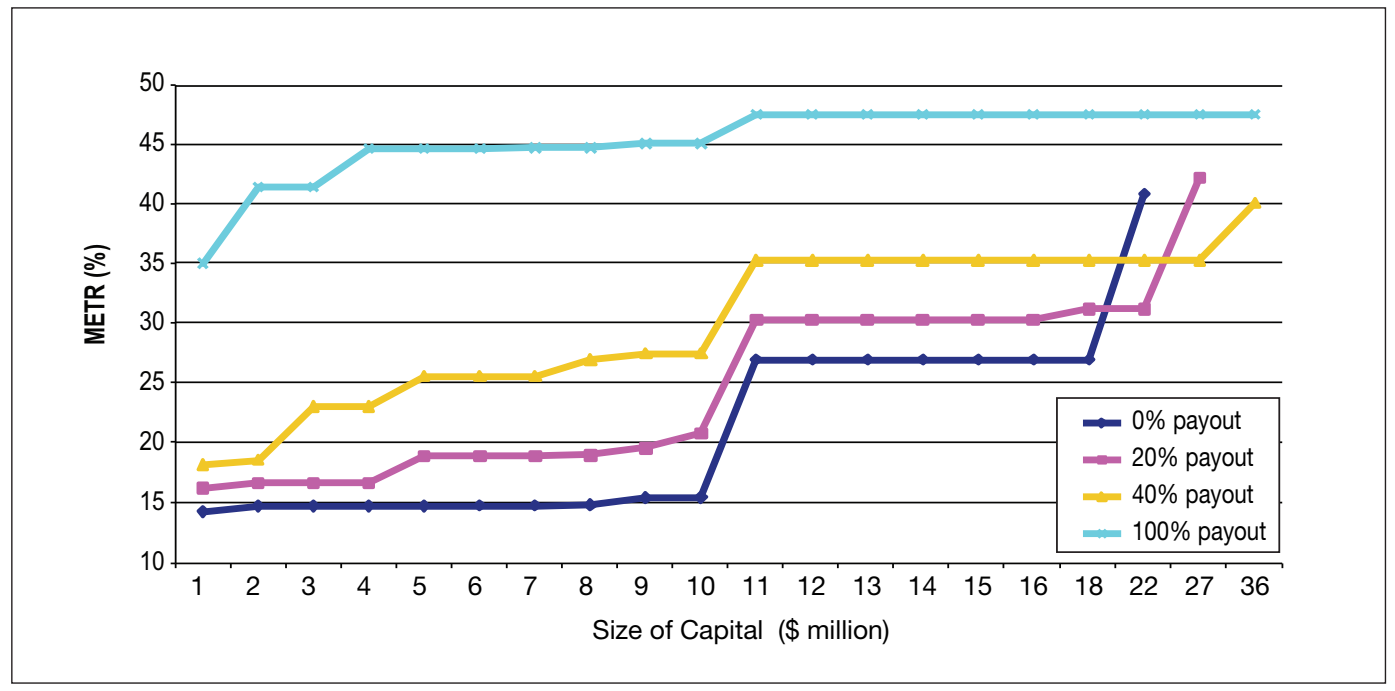

\section{F. Variation of Debt-to-Asset Ratios}

One of the main arguments for having a SBD is the disadvantage in financial accessibility encountered by small business. While the reasons for the statistically lower debt-to-asset ratio for small business (compared to large firms) are somewhat unclear, ${ }^{17}$ it is technically justifiable to use the debt-to-asset ratio to reflect the borrowing power of small business. Figure 6 presents a METR simulation for small business with varying debt-to-asset ratios.

\footnotetext{
17 In an extreme case, as categorized by Crawford and Freedman (note 8), some small businesses might be simply seen as "non-entrepreneurial lifestyle businesses" which have no need to raise funds through borrowing.
} 
FIGURE 6 Marginal Effective Tax Rate on Small Business

Simulation 4: 5\% Pre-tax Profit-to-Asset Ratio, 40\% Dividend Payout Ratio and Varying Debt-to-Asset Ratios

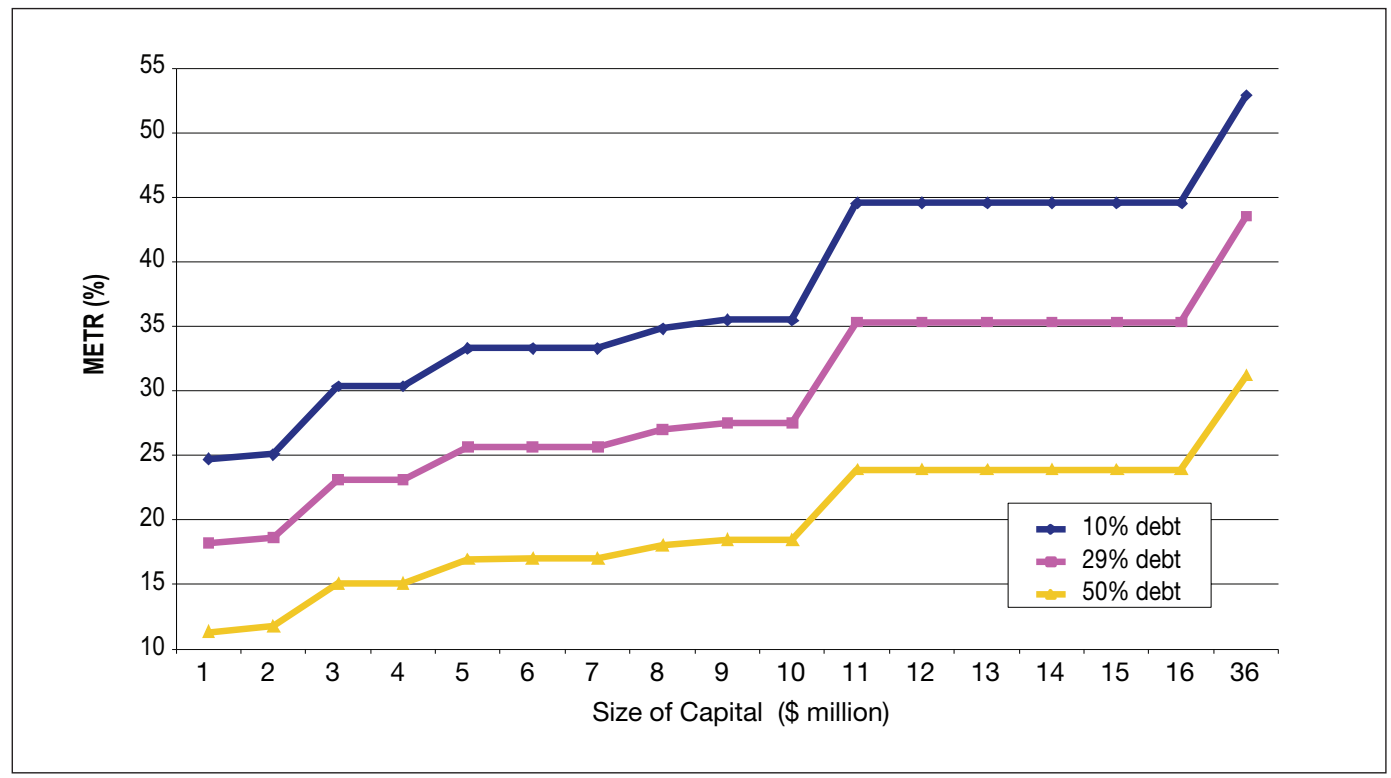

As the figure shows, the higher the debt-to-asset ratio (e.g., 50 percent), the lower the METR for small business will be and vice versa (e.g., compared to a 10 percent debt-to-asset ratio). ${ }^{18}$ This simulation at least illustrates that a tax reduction is not the only remedy for a financing disadvantage facing small business. For example, without advocating it due to the likely moral hazard problems that would ensue, directly reducing the possible financial barriers to small business (e.g., through a government loan guarantee) might be an option that may aid the effort to relieve our tax system from a duty of assisting small firms.

\section{POLICY IMPLICATIONS}

The overall aim of tax policy is to levy taxes in an efficient and fair manner with minimal compliance and administrative costs.

An efficient tax system is one that minimizes distortions in the decisions made by households and businesses with respect to the best use of economic resources. This would normally imply that taxes should be levied at similar rates on goods, services, businesses and labour among competing uses. At times, taxes might be used as an alternative to other public policies (e.g., government subsidies, regulations and spending programs) to influence economic behaviour. For example, in the case of pollution or research and development, markets fail to achieve an efficient allocation of resources when individuals or businesses do not take into account the beneficial (innovation) or harmful (pollution) spillover impact of their decisions on other parts of the economy. However, a case-by-case assessment is needed to best judge which type of policy (spending, tax reductions or regulation) are best able to influence economic activity.

18 In this model, personal taxes on interest income are irrelevant since it is assumed that financing is provided by banks - borrowing costs are determined by international capital markets (Canadian personal taxes are therefore irrelevant in this case). If, however, entrepreneurs provided debt financing, the estimated effective tax rates on capital would include personal taxes on borrowed funds. Such personal taxes are higher than dividend and capital gains taxes paid on equity income by investors, the latter two being reduced by the dividend tax credit and capital gains exclusion. 
Fairness is achieved by imposing similar burdens on individuals with similar resources. It might also imply levying different burdens on individuals when their ability to pay taxes differs. Fairness is best achieved by varying taxes paid by individuals since businesses can be owned by both the rich and the poor. Thus, in the interest of fairness, business taxes are best levied at similar rates across business activities while varying personal tax rates to accomplish fairness objectives.

The administrative costs for governments and compliance costs for taxpayers are minimized by keeping taxes as neutral and as simple as possible. The more complex the tax provisions, the greater the administrative and compliance costs since more "boundaries" must be defined and checked to determine the eligibility of a taxpayer's activities for special consideration.

More specifically, the role of the corporate tax is most efficient, fair and least costly in terms of administrative and compliance costs when it is levied at a single rate on a neutral, broad base.

\section{A. Specific Issues Related to Small Business}

Preferential taxation on small business has been suggested for two important reasons.

First, the administrative and compliance costs associated with the tax system are a greater burden on smaller businesses compared to larger companies. Certainly, Vaillancourt and Clemons provide conclusive evidence to suggest that the cost of compliance declines relative to firms' assets or revenue size. ${ }^{19}$ However, as these authors point out, compliance costs are substantial for both large and small firms, suggesting that broad reforms to simplify the tax system should certainly be an important consideration for tax policy to the benefit of all firms in the economy.

Second, small businesses have less access to international and domestic capital markets, forcing entrepreneurs to rely on more selective financing sources including banks, family and friends. Whether liquidity-constrained small businesses are faced with credit limitations is not easily proven, since they are able to access capital markets through financial institutions whose role is to match the interests of borrowers and lenders in markets. Undoubtedly, the economic cost of servicing loans is more expensive for small compared to large businesses (just as are other input costs), but this does not provide a basis for specific intervention.

Probably the most important argument in favour of small business support is with respect to information asymmetries in financial markets whereby smaller firms, being more reliant on funds from external sources, face higher financing costs even if they have good-quality projects. ${ }^{20}$ Research on this topic has spawned a rich literature on imperfect information that shows that markets can work in the presence of imperfect information if people trust signals about credit quality such as financial leverage, entrepreneurial stake in investments, dividend policy, etc. Signals work if good suppliers can separate themselves from the "lemons"-a minimal condition needed for separation being that the signal is more expensive for the lemons to adopt compared to the better quality companies. Nonetheless, even with separation of the good from the bad, inefficiency is present since bad-quality companies operating in the market make it more expensive for good quality ones to issue securities to less informed investors.

19 F. Vaillancourt and J. Clemons, "Compliance and Administrative Costs of Taxation in Canada," in The Impact and Cost of Taxation in Canada: Case for a Flat Tax, ed. by J. Clemens, Fraser Institute, 2008, 55-102.

20

Markets can breakdown if good firms cannot separate themselves from the bad. See G. Akerlof, "The Market for Lemons: Quality Uncertainty and the Market Mechanism,” Quarterly Journal of Economics, 48(3), 1970, pp. 488-500. 
In the past several years, several disparate papers on policy applications in models with imperfect information have provided a reasoned approach to improve the functioning of markets. ${ }^{2 l}$ The key role of regulations or fiscal policies is that they should make it harder for bad players to mimic good players. In other words, it is important to "tax" and not "subsidize" signals so that good players are less squeezed out of the market by lemons. For example, new equity financing subsidies actually could worsen information asymmetries since they would make it easier for bad firms to copy good firms (the good firms need less new equity financing since they have stronger cash flows and signal this strength through greater use of retained earnings). On the other hand, investment credits or allowances make it easier for good firms to separate themselves from poorer quality companies.

\section{B. Some Practical Recommendations}

A basic principle underlying our recommendations is to adopt policies that assist small businesses to overcome economic barriers to their growth and avoid tax policies that themselves create those barriers. We specifically suggest replacing the small business tax deduction and lifetime capital gains exemption with better incentives that promote rather than hinder growth. Three specific tax initiatives are suggested:

- Incentives for investment in depreciable assets: To encourage small businesses to grow without creating tax barriers to growth, the government could adopt expensing of capital up to a certain limit that would be available to all firms. For example, to maintain $\$ 1$ million capital stock, annual capital investment would need to be about $\$ 70,000$ (assuming an average depreciation rate of seven percent). If the first $\$ 70,000$ of capital expenditure were expensed rather than depreciated for tax purposes, small businesses would be able to benefit from a lower tax cost until they build up their capital to a reasonable level. The only difference is that this incentive would be available to both large and small companies. When companies get larger there would be no clawback of the benefit.

This approach to providing investment incentive for small business has been used in the United Kingdom. While it does have a higher fiscal cost since the incentive is available to all businesses, it imposes a smaller "wall" since it would be immaterial to large and growthoriented businesses.

- Capital gains incentive for small business going public: Canadian small business capital gains tax policy is geared towards private companies. As soon as companies become public, they lose many of the tax benefits they have been entitled to including the small business tax deduction and lifetime capital gains exemption (the latter can be realized by owners crystallizing their gains at conversion). ${ }^{22}$ In other words, incentives create a barrier to growth when firms become public.

As an alternative to the lifetime capital gains exemption, we recommend a 50 percent reduction in capital gains tax for shares issued by small businesses when they become public. The purchaser would have to hold the shares for five years. Qualifying shares could be limited to small businesses with less than $\$ 50$ million in assets. The US has had a similar tax incentive structured to help small businesses grow in this manner.

21 J. Mintz, "Policy Perspectives on Capital Market Issues," in Capital Market Issues, ed. by P. Halpern, University of Calgary Press, 1997, pp. 729-752.

22 The lifetime capital gains exemption has been used by large public companies to provide additional benefits to specific shareholders. For example, a private company is established for manager-shareholders to receive income from the corporation. Each shareholder of the private company can then claim the $\$ 750,000$ capital gains exemption. 
- Reducing the lock-in effect of capital gains taxes - capital gains tax deferral accounts: One of the problems with capital gains taxes, which applies only when assets are divested, is that they encourage people to hold assets rather than rolling them over into alternative investments. The "lock-in" effect of capital gains taxes can therefore undermine economic efficiency if people continue holding assets rather than shifting to those investments with better economic returns. It also limits the ability of small business owners to cash out their gains, thereby making exit harder. The current capital gains exemption for shares in private companies and farm and fishing property helps small business owners to cash out but it also creates a barrier to growth as we have already discussed.

At present, investors in small businesses can defer capital gains on the sale of small business shares by purchasing shares of another small business within a specified time period. The intent of the provision has been to enable small business owners to readjust their portfolios and avoid capital gains taxes that would be triggered at the time of the sale. While this provision does provide some relief, it is clearly very limited in scope. It does not help small business owners who choose to exit a business by investing proceeds in the market rather than looking for another small business venture. It also discriminates against investors in other types of businesses who look to reallocate their portfolios to achieve better returns.

We would recommend a more general approach whereby Canadian investors in small businesses would be able to reinvest proceeds in a "capital gains tax deferral account" whereby no capital gains tax is paid until the asset is sold for other purposes than investing generally. ${ }^{23}$ In the capital gains deferral account, any assets that yield taxable capital gains (such as investments in real estate, public corporation securities, etc.) would enable entrepreneurs and other investors to roll over assets on a deferral basis until the assets are disposed of. While we would suggest developing the capital gains deferral account to apply widely to all investors, it could be limited to owners of smaller public and private corporations on a limited basis to reduce the fiscal cost of the incentive.

The abolition of the lifetime capital gains exemption would reduce the cost of the initiative. Also, the tax deferral account would reduce the need to have a capital gains tax incentive to encourage small businesses to go public as discussed above, since investors could defer capital gains taxes altogether when firms become public by placing the assets in the capital gains tax deferral account.

\section{CONCLUSION}

By illustrating the threshold effect of the Canadian small business tax regime under varying business scenarios, our METR simulations do not support the pro-growth argument for the small business deduction in general and the argument for increasing the income threshold for the SBD in particular. Instead, our simulations show that,

- As long as there is a specified size for the SBD, the threshold effect on business growth is unavoidable regardless of the level of income or capital threshold set for the SBD

(Figures 1 and 3).

${ }^{23}$ Op cit supra note 13 . 
- A higher income threshold provides a greater tax advantage for less profitable firms as compared to those that are highly profitable and hence have greater growth potential (Figure 4).

- The inconsistency in tax design (e.g., intending to support small firms on the one hand, but demonstrating insensitivity to the overall tax environment for business in general) should be dealt with more urgently than by single-mindedly enhancing the SBD-with the results shown by some high provincial METRs in Figure 2 (e.g., the highest provincial METRs in PEI and Manitoba respectively).

- The current SBD regime complicates our business tax system. In particular, in conjunction with the well-intended dividend tax credit regime, it does not add much value to tax efficiency but causes greater compliance and administrative costs and encourages more wasteful tax planning (Figure 5).

- Several changes to the tax system could be adopted that would provide important relief especially for small businesses without creating new tax barriers. We include in our recommendations (i) expensing of capital investment up to a limit, (ii) a capital gains tax incentive for companies to go public and (iii) a capital gains tax deferral account.

In conclusion, in order to justify the SBD and further reform our small business tax regime, the common reasoning for having the SBD, such as the postulated existence of capital market failure that hampers the financing capacity of small businesses, and the regressivity of compliance costs and asymmetry of profits and losses faced by small businesses, requires a thorough investigation. Such investigation will provide a knowledge foundation for reforming our SBD regime as an integral part of the overall tax system. 


\section{APPENDIX A:}

\section{TAX PROVISIONS AFFECTING SMALL BUSINESSES}

\begin{tabular}{|c|c|c|}
\hline & Federal & Provincial \\
\hline \multicolumn{3}{|c|}{ CORPORATE TAX PROVISIONS } \\
\hline $\begin{array}{l}\text { Small Business } \\
\text { Deduction }\end{array}$ & $\begin{array}{l}\text { - The federal corporate tax rate on CCPCs with } \\
\text { a taxable capital below } \$ 10 \text { million is } \\
\text { reduced to } 11 \text { percent on active business } \\
\text { income up to } \$ 500,000 \text {. } \\
\text { - The small business deduction is restricted on } \\
\text { a straight-line basis for such CCPCs with } \\
\text { taxable capital in excess of } \$ 10 \text { million and } \\
\text { below } \$ 15 \text { million, beyond which the } \\
\text { deduction is eliminated entirely. }\end{array}$ & $\begin{array}{l}\text { - Provincial corporate income tax rates on CCPCS } \\
\text { are reduced in all provinces to a lower rate up } \\
\text { to } \$ 500,000 \text { in business income except } \\
\text { thresholds lower in Manitoba and Nova Scotia } \\
(\$ 400,000) \text {. }\end{array}$ \\
\hline $\begin{array}{l}\text { Research and } \\
\text { Development Tax } \\
\text { Credit }\end{array}$ & $\begin{array}{l}\text { - Higher credit at } 35 \text { percent instead of } \\
20 \text { percent for smaller businesses. } \\
\text { - Annually limited to } \$ 3 \text { million of R\&D } \\
\text { expenditure. } \\
\text { - Credit for small business refundable at } \\
100 \text { percent (current expenses) and } \\
40 \text { percent (capital expenses) } \\
\text { - Limit phased out between } \$ 500,000 \text { and } \\
\$ 800,000 \text { expenditure or } \$ 10 \text { to } \$ 50 \text { million } \\
\text { in taxable capital. }\end{array}$ & $\begin{array}{l}\text { - Higher credit rate for smaller firms in Ontario } \\
\text { (innovation credit) and Quebec. Alberta limits its } \\
10 \text { percent credit to the } \\
\text { - Ontario innovation credit is } 10 \text { percent with } \\
\text { limits similar to federal limits for small } \\
\text { businesses. } \\
\text { - Quebec credit of } 37.5 \text { percent for companies } \\
\text { less than } \$ 50 \text { million in assets and R\&D wage } \\
\text { costs below } \$ 3 \text { million. Rate phased down to } \\
17.5 \text { percent for assets between } \$ 50 \text { and } \$ 75 \\
\text { million assets. }\end{array}$ \\
\hline Tax Holidays & & $\begin{array}{l}\text { Holidays given for targeted activities. Specific to } \\
\text { CCPCs are the following: } \\
\text { - Newfoundland and Labrador ( } 5 \text { years) } \\
\text { - Nova Scotia ( } 3 \text { years) } \\
\text { - Quebec manufacturing in remote areas } \\
\text { ( } 75 \text { percent of income below } \$ 20 \text { million paid- } \\
\text { up capital) }\end{array}$ \\
\hline $\begin{array}{l}\text { Capital Taxes (non- } \\
\text { financial) as of } 2010\end{array}$ & $\mathrm{~N} / \mathrm{A}$ & $\begin{array}{l}\text { Only Quebec and Nova Scotia, impose such a tax } \\
\text { on capital above a certain threshold. They are also } \\
\text { phasing out capital taxes by } 2012 \text {. }\end{array}$ \\
\hline \multicolumn{3}{|c|}{ PERSONAL TAX PROVISIONS } \\
\hline $\begin{array}{l}\text { Graduated Personal } \\
\text { Income Tax Schedule }\end{array}$ & Rates vary by income. & Rates vary by income. \\
\hline Dividend Tax Credit & $\begin{array}{l}\text { Two dividend tax credits - } 15 \text { percent (2012) } \\
\text { for eligible dividends and } 13.33 \text { percent for } \\
\text { ineligible dividends to reflect low small } \\
\text { business rate. }\end{array}$ & $\begin{array}{l}\text { Similar to federal level with credit rates with rates } \\
\text { varying by province. }\end{array}$ \\
\hline $\begin{array}{l}\text { Lifetime Capital } \\
\text { Gains Exemption }\end{array}$ & $\begin{array}{l}\text { Capital gains on the disposition of shares in a } \\
\text { CCPC are exempt from tax (as of } 2010 \text {, equal } \\
\text { to } \$ 750,000 \text { ). Business must hold at least } 90 \\
\text { percent of assets in Canada and derive over } \\
\text { half of income from active business income. }\end{array}$ & Same \\
\hline $\begin{array}{l}\text { Capital Gain } \\
\text { Deferral }\end{array}$ & $\begin{array}{l}\text { Deferral of capital gains on shares held in a } \\
\text { small business if replaced by another small } \\
\text { business investment. Small businesses } \\
\text { restricted to less than } \$ 50 \text { million in asset size } \\
\text { at times shares are issued. }\end{array}$ & Same \\
\hline
\end{tabular}




\begin{tabular}{|c|c|c|}
\hline & Federal & Provincial \\
\hline \multicolumn{3}{|c|}{ PERSONAL TAX PROVISIONS cont'd } \\
\hline $\begin{array}{l}\text { Labour Sponsored } \\
\text { Venture Capital } \\
\text { Credit }\end{array}$ & $\begin{array}{l}\text { - Tax credit for investments in labour- } \\
\text { sponsored venture capital firms equal to } \\
15 \text { percent of amount up to } \$ 5000 \text {. } \\
\text { - Investments by LSVCC in small businesses } \\
\text { with less than } \$ 10 \text { million in assets are } \\
\text { counted } 1.5 \text { the amount towards the } \\
60 \text { percent business investment requirement. }\end{array}$ & $\begin{array}{l}\text { Most provinces have a similar credit except for } \\
\text { Ontario (being phased out although a new retail } \\
\text { credit has been introduced) and Alberta. }\end{array}$ \\
\hline $\begin{array}{l}\text { Stock Options } \\
\text { (CCPC) }\end{array}$ & $\begin{array}{l}\text { Employment benefits arising from the exercise } \\
\text { of stock options issued by a CCPC to an arm's } \\
\text { length employee are deferred for tax purposes } \\
\text { until the shares are sold. }\end{array}$ & Same \\
\hline $\begin{array}{l}\text { Equity Tax Credits } \\
\text { for Investors }\end{array}$ & None & $\begin{array}{l}\text { - Quebec SMB Growth Plan - deduction for } \\
\text { investments with a minimum of three years in } \\
\text { shares of enterprises with less than } \$ 100 \\
\text { million in assets. } \\
\text { - Alberta stock savings plan provides a tax credit } \\
\text { for investments in eligible emerging or } \\
\text { expanding companies. } \\
\text { - New Brunswick small business investor credit of } \\
30 \text { percent (maximum credit of } \$ 24,000 \text { ) is } \\
\text { provided for equity investments held for four } \\
\text { years in small businesses with less than } \$ 40 \\
\text { million in assets. } \\
\text { - Nova Scotia's equity tax credit of } 30 \text { percent } \\
\text { (maximum credit of } \$ 15,000 \text { ) in small } \\
\text { businesses of less than } \$ 25 \text { million assets. } \\
\text { Additional credits for community development } \\
\text { initiatives. } \\
\text { - Newfoundland and Labrador provide a } \\
20 \text { percent (35 percent outside of northeast } \\
\text { Avalon) direct-equity tax credit for small } \\
\text { business investments (less than } \$ 20 \text { million in } \\
\text { assets or } 50 \text { full-time employees) in selected } \\
\text { industries. } \\
\text { - Yukon provides a small business investment tax } \\
\text { credit at } 25 \text { percent (maximum } \$ 25,000 \text { ) for } \\
\text { Yukon businesses of less than } \$ 25 \text { million in } \\
\text { capitalization. } \\
\text { - Manitoba provides an equity tax credit for } \\
\text { investors of five percent up to } \$ 1,500 \text { (up to } \\
\text { June } 2008 \text { ) and community enterprise tax credit } \\
\text { (30 percent up to } \$ 9,000 \text { ). }\end{array}$ \\
\hline Capital Losses & $\begin{array}{l}\text { Capital losses on the sale of shares or bonds } \\
\text { held in Canadian-controlled small businesses } \\
\text { may be deducted from any source of income }\end{array}$ & Same \\
\hline \multicolumn{3}{|l|}{ SALES TAXES } \\
\hline Value-Added Taxes & $\begin{array}{l}\text { GST: Small trader exemption for sales less than } \\
\$ 30000 \text {. Quick method (remit } 3 / 5 \text { of } \\
\text { collections with no input tax credits) for } \\
\text { businesses with less than } \$ 200,000\end{array}$ & $\begin{array}{l}\text { - HST in British Columbia, Ontario, Nova Scotia, } \\
\text { New Brunswick and Newfoundland \& Labrador - } \\
\text { similar exemptions } \\
\text { - Quebec Sales Tax: Small trader exemption same } \\
\text { as federal GST. }\end{array}$ \\
\hline \multicolumn{3}{|l|}{$\begin{array}{l}\text { PAYROLL TAXES } \\
\end{array}$} \\
\hline $\begin{array}{l}\text { Provincial payroll } \\
\text { taxes }\end{array}$ & $\mathrm{N} / \mathrm{A}$ & $\begin{array}{l}\text { Provinces apply employer payroll taxes with } \\
\text { exemptions or low rates for employers with smaller } \\
\text { payroll costs. }\end{array}$ \\
\hline
\end{tabular}




\section{APPENDIX B \\ Financial Performance Indicators for Canadian Businesses (Non-Financial Industries, excluding Holding Companies and Head Offices)}

\begin{tabular}{|lrrr|}
\hline Financial ratios (average, all firms with revenue under \$5 million) & $\mathbf{2 0 0 4}$ & $\mathbf{2 0 0 5}$ & $\mathbf{2 0 0 6}$ \\
\hline Return on net operating assets & 8.8 & 9.6 & 11.6 \\
Pre-tax profit to assets & 3.9 & 4.8 & 6.1 \\
Return on capital employed $^{\text {Return on equity }}{ }^{1}$ & 8.3 & 9.1 & 10.9 \\
Debt-to-equity $^{1}$ & 17.1 & 18.8 & 21.1 \\
Liability to assets & 0.4 & 0.4 & 0.4 \\
\hline
\end{tabular}

${ }^{1}$ Firms with zero or negative equity are excluded from the "Return on equity" and "Debt-to-equity" ratios.

Definitions of any of the above may be found at:

http://www.statcan.ca/english/freepub/61-219-XIE/2006000/technote5.htm

\begin{tabular}{|lc|}
\hline Income / Balance Sheet Data & Average (in dollars) \\
\hline Total revenue & 618,436 \\
Cost of goods sold & 406,734 \\
Net profit/ loss before tax & 36,074 \\
Current assets & 199,193 \\
Total assets & 523,048 \\
Current liabilities & 120,902 \\
Total liabilities & 277,534 \\
Retained earnings & 135,577 \\
Total equity & 245,515 \\
\hline
\end{tabular}

Source: Statistics Canada, 61-219-XIE. 


\section{APPENDIX C}

\section{METHODOLOGY FOR ESTIMATING MARGINAL EFFECTIVE TAX RATES}

This appendix is provided to those readers who are interested in knowing the formulas used for calculating marginal effective tax rates on capital at the small business level. The standard method used to estimate marginal effective tax rates is extensively modified to reflect changing tax rates as exemplified by the Canadian tax structure. ${ }^{24} \mathrm{~A}$ firm invests in capital until the rate of return on capital is equal to the depreciation, financing and tax costs of holding capital. The small business borrows debt from third parties (e.g., banks). The small business owner funds equity (we assume there is only one owner in the model).

Given that the corporate and personal tax rates rise with income and the size of the firm, the investor decisions account for shifts in tax rates. The most important change is the rise in the corporate income tax rate when the small business becomes taxed as a regular business. This issue is similar to modeling tax-loss companies when tax rates increase after the losses are expired (with the time taken to reach the threshold depending on asset size or profits). This is a fairly complicated model whereby the time-value of tax depreciation deductions increases as the firm reaches the date in which it becomes taxable. The cost of investing one year early is to give up higher tax depreciation allowances after the firm reaches a higher corporate income tax rate. If the firm always expects to remain below the threshold, the model is simplified since the tax rates are not expected to change.

We do not provide the full derivation of the model. However, readers may consult earlier work relevant to this type of problem. ${ }^{25}$

The formulas derived from the theoretical model incorporate miscellaneous taxes such as capital taxes and sales taxes on capital purchases. Following are the general formulas used in this study. Note that these formulas are not indexed for time (given shifts in tax rates) except in cases when the time factors are relevant for definition. For simplicity, we provide formulas for changes in corporate tax rates only (not for changes in personal tax rates that would affect the discount rate for evaluating firm investments).

\section{(I) MARGINAL EFFECTIVE TAX RATE (t)}

The marginal effective tax rate on a given type of capital is defined as the proportional difference between the gross-of-tax rate of return $\left(\mathrm{r}^{\mathrm{G}}\right)$ required by a firm and the net-of-tax rate of return $\left(\mathrm{r}^{\mathrm{N}}\right)$ required by the equity investor. $\mathrm{r}^{\mathrm{G}}$ is the marginal revenue product (or user cost of capital, in equilibrium) net of economic depreciation. The after-tax rate of return is the return on equity securities held by the owner. Thus, the effective tax rate $(t)$ is defined as

$$
\mathrm{t}=\left(\mathrm{r}^{\mathrm{G}}-\mathrm{r}^{\mathrm{N}}\right) / \mathrm{r}^{\mathrm{G}}
$$

\footnotetext{
${ }^{24}$ For example, for countries levying gross-receipts tax, which does not exist in Canada, formulas presented in this appendix would need to be modified.

25 See Jack M. Mintz, “Tax Holidays and Investment,” World Bank Economic Review, 4, No. 1, 1990, 81-102.
} 


\section{(II) THE NET-OF-TAX RATE OF RETURN ON CAPITAL $\left(r^{\mathrm{N}}\right)$}

The net-of-tax rate of return on capital is defined by the formula

$$
\mathrm{r}^{\mathrm{N}}=\beta \mathrm{i}+(1-\beta) \varrho(1-\mathrm{m})-\pi
$$

whereby $i$ is the interest rate on debt financing (we ignore personal taxes on third-party debt which is assumed to be provided by banks), $\varrho$ is pre-personal tax return on equity, $\mathrm{m}$ weighted average personal tax rates on dividends and capital gains (accrual-equivalent basis) and $\pi$ is the rate of inflation. The after-tax return on equity, adjusted for inflation, $\varrho(1-m)-\pi$, is the aftertax rate of return on capital required by the small business owner, which would be at least equal to the after-tax returns available on alternative investment opportunities.

\section{(III) THE REAL COST OF FINANCING $\left(\mathrm{r}^{\mathrm{f}}\right)$}

The real cost of financing $\left(\mathrm{r}^{\mathrm{f}}\right)$ for the small business is one of the main components of cost of capital for the small business corporation, or gross-of-tax rate of return $\left(\mathrm{r}^{\mathrm{G}}\right)$ on capital. The real cost of financing $\left(\mathrm{r}^{\mathrm{f}}\right)$ is defined by

$$
\mathrm{r}^{\mathrm{f}}=\beta \mathrm{i}(1-\mathrm{U})+(1-\beta) \varrho-\pi
$$

with $\beta=$ the ratio of debt to assets ratio, $i=$ cost of debt, $U=$ the statutory corporate income tax rate (which depends on size), $\varrho=$ cost of equity, and $\pi=$ inflation rate. That is, the cost of financing for the firm is the weighted-average cost of financing net of the inflation rate. Note that the cost of finance will shift in time due to two factors-higher corporate income tax rates and a higher personal tax rate on equity income.

\section{(IV) THE GROSS-OF-TAX RATE OF RETURN ( ${ }^{\mathrm{G}}$ ) ON CAPITAL}

\section{A. Depreciable assets (i.e. buildings and machinery and equipment)}

$\left.\mathrm{r}^{\mathrm{G}}=\left(\delta+\mathrm{r}^{\mathrm{f}}\right)(1+\mathrm{z})(1-\mathrm{k})\left\{1-\mathrm{A}_{\mathrm{t}}\right)\right\} /\left(1-\mathrm{U}_{\mathrm{t}}\right)+\left(1+\mathrm{r}^{\mathrm{f}}+\pi\right)\left(\mathrm{A}_{\mathrm{t}}-\mathrm{A}_{\mathrm{t}-1}\right) /\left(1-\mathrm{U}_{\mathrm{t}}\right) \quad$ for $\mathrm{t}<\mathrm{T}$ and

$\begin{array}{ll}\mathrm{r}^{\mathrm{G}}=\left(\delta+\mathrm{r}^{\mathrm{f}}\right)(1+\mathrm{z})(1-\mathrm{k})[1-\mathrm{A}](1-\mathrm{U})-\delta & \text { for } \mathrm{t}>\mathrm{T}\end{array}$

with the present value of tax benefits from depreciation deductions net of capital tax payments, A, equal to

$$
\begin{array}{ll}
A_{t}=\sum_{s=t} \infty\left[\left(1+R_{s}\right)^{-(s-t)}\left\{U_{t} \alpha(1-\alpha)^{-(s-t)}\right]^{-}-\tau\left(1-U_{t}\right)(1-\delta)^{-(s-t)}\right\} & \text { for } t<T . \\
A=U \alpha /\left(\alpha+r^{f}+\pi\right)-\tau(1-U) /\left(\delta+r^{f}+\pi\right) & \text { for } t>T .
\end{array}
$$

Where $\mathrm{r}^{\mathrm{f}}=$ real cost of financing as defined above, $\delta=$ economic depreciation rate, $\mathrm{k}=$ investment tax credit rate, $\tau=$ capital tax rate, $\alpha=$ tax depreciation rate and $\mathrm{z}$ is the sales tax rate on capital purchases. Prior to full taxation, the present value of tax depreciation allowances changes reflecting shifts in corporate tax rates over time. 


\section{B. Inventory}

$\mathrm{r}^{\mathrm{G}}=\left(\mathrm{r}^{\mathrm{f}}+\mathrm{U} \pi\right) /(1-\mathrm{U})+\tau$

\section{Land}

$\mathrm{r}^{\mathrm{G}}=\mathrm{r}^{\mathrm{f}}\left[1+\tau(1-\mathrm{U}) /\left(\mathrm{r}^{\mathrm{f}}+\pi\right)\right] /(1-\mathrm{U})$

Important Limitation: In our calculations, the time taken to reach the threshold is unknown and can be avoided if certain financing decisions are used. For empirical purposes, the present value of tax depreciation allowances changes little, $\left(A_{t}\right.$ is close enough to $\left.A_{t-1}\right)$, thereby simplifying calculations of effective tax rates. The estimates provided in the figures result in somewhat lower marginal effective tax rate calculations during the low-tax rate period when we ignore the changes in the tax value of depreciation allowances.

\section{(V) AGGREGATION}

The METR for a given industry is the proportional difference between the weighted average of the before-tax rate of return by as set type and the after-tax rate of return; the latter is the same across asset types within a given sector. That is, the marginal effective tax rate for the ith industry $t_{i} \cdot t_{i}$ is calculated as following:

$$
\mathrm{t}_{\mathrm{i}}=\left(\Sigma_{\mathrm{j}} \mathrm{r}_{\mathrm{ij}} \mathrm{w}_{\mathrm{ij}}-\mathrm{r}_{\mathrm{i}}^{\mathrm{N}}\right) / \Sigma_{\mathrm{j}} \mathrm{r}_{\mathrm{ij}} \mathrm{w}_{\mathrm{ij}}
$$

where $\mathrm{j}$ denotes asset type (i.e. investments in buildings, machinery, inventories, and land), and $\mathrm{w}_{\mathrm{ij}}$ denotes the weight of asset type $\mathrm{j}$ in industry $\mathrm{i}$. 


\section{About the Authors}

\section{Dr. Jack Mintz}

\section{The James S. \& Barbara A. Palmer Chair in Public Policy}

Jack M. Mintz was appointed the Palmer Chair in Public Policy at the University of Calgary in January 2008.

Widely published in the field of public economics, he was touted in a 2004 UK magazine publication as one of the world's most influential tax experts. He serves as an Associate Editor of International Tax and Public Finance and the Canadian Tax Journal, and is a research fellow of CESifo, Munich, Germany, and the Centre for Business Taxation Institute, Oxford University. $\mathrm{He}$ is a regular contributor to Canadian Business and the National Post, and has frequently published articles in other print media.

Dr. Mintz presently serves on several boards including Brookfield Asset Management, Imperial Oil Limited, Morneau Shepell, and Royal Ontario Museum. He was also appointed by the Federal Minister of Finance to the Economic Advisory Council to advise on economic planning and served as research director for the Federal-Provincial Minister's Working Group on Retirement Income Research.

Dr. Mintz held the position of Professor of Business Economics at the Rotman School of Business from 1989-2007 and Department of Economics at Queen's University, Kingston, 1978-1989. He was a Visiting Professor, New York University Law School, 2007; President and CEO of the C.D. Howe Institute from 1999-2006; Clifford Clark Visiting Economist at the Department of Finance, Ottawa; Chair of the federal government's Technical Committee on Business Taxation in 1996 and 1997; and Associate Dean (Academic) of the Faculty of Management, University of Toronto, 1993-1995. He was founding Editor-in-Chief of International Tax and Public Finance, published by Kluwer Academic Publishers from 1994-2001, and recently chaired the Alberta Financial and Investment Policy Advisory Commission reporting to the Alberta Minister of Finance.

In 2002, Dr. Mintz's book, Most Favored Nation: A Framework for Smart Economic Policy, was winner of the Purvis Prize for best book in economic policy and runner-up for Donner Prize for best book in public policy.

Dr. Mintz has consulted widely with the World Bank, the International Monetary Fund, the Organization for Economic Co-operation and Development, the governments of Canada, Alberta, New Brunswick, Ontario, and Saskatchewan, and various businesses and nonprofit organizations.

Dr. Duanjie Chen is a Research Fellow at The School of Public Policy, University of Calgary. Over the past two decades, she served as a consultant to various international organizations, national government bodies, and business and non-profit organizations. She has published numerous articles and papers in the area of public finance. 


\section{ABOUT THIS PUBLICATION}

The School of Public Policy Research Papers provide in-depth, evidence-based assessments and recommendations on a range of public policy issues. Research Papers are put through a stringent peer review process prior to being made available to academics, policy makers, the media and the public at large. Views expressed in The School of Public Policy Research Papers are the opinions of the author(s) and do not necessarily represent the view of The School of Public Policy.

\section{OUR MANDATE}

The University of Calgary is home to scholars in 16 faculties (offering more than 80 academic programs) and 36 Research Institutes and Centres including The School of Public Policy. Under the direction of Jack Mintz, Palmer Chair in Public Policy, and supported by more than 100 academics and researchers, the work of The School of Public Policy and its students contributes to a more meaningful and informed public debate on fiscal, social, energy, environmental and international issues to improve Canada's and Alberta's economic and social performance.

The School of Public Policy achieves its objectives through fostering ongoing partnerships with federal, provincial, state and municipal governments, industry associations, NGOs, and leading academic institutions internationally. Foreign Investment Advisory Committee of the World Bank, International Monetary Fund, Finance Canada, Department of Foreign Affairs and International Trade Canada, and Government of Alberta, are just some of the partners already engaged with the School's activities.

For those in government, The School of Public Policy helps to build capacity and assists in the training of public servants through degree and non-degree programs that are critical for an effective public service in Canada. For those outside of the public sector, its programs enhance the effectiveness of public policy, providing a better understanding of the objectives and limitations faced by governments in the application of legislation.

\section{DISTRIBUTION}

Our publications are available online at www.policyschool.ca.

\section{DISCLAIMER}

The opinions expressed in these publications are the authors' alone and therefore do not necessarily reflect the opinions of the supporters, staff, or boards of The School of Public Policy.

\section{COPYRIGHT}

Copyright (C) 2011 by The School of Public Policy.

All rights reserved. No part of this publication may be reproduced in any manner whatsoever without written permission except in the case of brief passages quoted in critical articles and reviews.

\section{ISSN}

1919-112x SPP Research Papers (Print)

1919-1138 SPP Research Papers (Online)

\section{DATE OF ISSUE}

May 2011

\section{MEDIA INQUIRIES AND INFORMATION}

For media inquiries, please contact Morten Paulsen at 403-453-0062.

Our web site, www.policyschool.ca, contains more information about The School's events, publications, and staff.

\section{DEVELOPMENT}

For information about contributing to The School of Public Policy, please contact Candice Naylen by telephone at 403-210-7099 or by e-mail at cnaylen@ucalgary.ca.

\section{EDITOR}

Timothy Giannuzzi 


\section{RECENT PUBLICATIONS BY THE SCHOOL OF PUBLIC POLICY}

IS THIS THE END OF THE TORY DYNASTY? THE WILDROSE ALLIANCE IN ALBERTA POLITICS http:// policyschool.ucalgary.ca/files/publicpolicy/wildrose\%20online\%20final3.pdf Anthony M. Sayers \& David K. Stewart | May 2011

CANADA'S WORLD CAN GET A LOT BIGGER: THE GROUP OF 20, GLOBAL GOVERNANCE AND SECURITY http:// policyschool.ucalgary.ca/files/ publicpolicy/G20\%20Heinbecker.pdf

Paul Heinbecker | May 2011

CAN THE G-20 SAVE THE ENVIRONMENT? POTENTIAL IMPACT OF THE G-20 ON INTERNATIONAL ENVIRONMENT POLICY

http:/ / policyschool.ucalgary.ca/files/publicpolicy/G20\%20.pdf

Barry Carin | April 2011

THE IMPACT OF SALES TAX REFORM ON ONTARIO CONSUMERS:

A FIRST LOOK AT THE EVIDENCE

http:// policyschool.ucalgary.ca/files/publicpolicy/ontario\%20sales\%20tax\%20reform4.pdf Michael Smart | March 2011

CANADA'S TAX COMPETITIVENESS RANKING: MOVING TO THE AVERAGE BUT BIASED AGAINST SERVICES http:/ / policyschool.ucalgary.ca/files/ publicpolicy/2010tax\%20comp\%20rank\%20online.pdf Jack Mintz \& Duanjie Chen | February 2011

FEDERAL-PROVINCIAL BUSINESS TAX REFORMS: A GROWTH AGENDA WITH COMPETITIVE RATES AND A NEUTRAL TREATMENT OF BUSINESS ACTIVITIES

http:/ / policyschool.ucalgary.ca/files/ publicpolicy/fed\%20prov\%20tax\%20reform\%201a.pdf Jack Mintz \& Duanjie Chen | January 2011

FIXING THE FISCAL IMBALANCE: TURNING GST REVENUES OVER TO THE PROVINCES IN EXCHANGE FOR LOWER TRANSFERS

http:/ / policyschool.ucalgary.ca/files/publicpolicy/GST\%20Boessenkool\%20online3.pdf

Kenneth J. Boessenkool | December 2010

ETHICAL RISKS OF ENVIRONMENTAL POLICIES: THE CASE OF ETHANOL IN NORTH AMERICA http:// policyschool.ucalgary.ca/files/ publicpolicy/BiofuelsJordaanfinal.pdf

S. M. Jordaan \& M. C. Moore | December 2010

CANADA, THE G8, AND THE G20: A CANADIAN APPROACH TO SHAPING GLOBAL GOVERNANCE IN A SHIFTING INTERNATIONAL ENVIRONMENT http:// policyschool.ucalgary.ca/files/publicpolicy/SMITH_finalfinal.pdf

Gordon S. Smith \& Peter C. Heap | November 2010

DIFFERENTIATING CANADA: THE FUTURE OF THE CANADA-US RELATIONSHIP http:// policyschool.ucalgary.ca/files/publicpolicy/dobsonkuzmanovic\%20online.pdf Wendy Dobson \& Diana Kuzmanovic | November 2010

EXPANDING CANADA PENSION PLAN RETIREMENT BENEFITS: ASSESSING BIG CPP PROPOSALS http:/ / policyschool.ucalgary.ca/ files/publicpolicy/Kesselman\%20CPP\%20online.pdf

Jonathan R. Kesselman | October 2010

SECURITIES REGULATION IN CANADA AT A CROSSROADS

http://policyschool.ucalgary.ca/files/publicpolicy/Lortie\%20online.pdf

Pierre Lortie | October 2010 